\title{
炭素鋼の低速捩り疲労変形に及ぼす温度の影響*
}

\author{
桜井忠一林山田攼林柿内正昭**
}

\section{Effect of elevated Temperature on the Fatigue Deformation of Carbon Steel Caused by Slow Cyclic Torsional Stress}

\author{
by \\ Tadakazu Sakurai, Iwao Yamada and Masaaki KaKiUchi \\ (Himeji Technical College)
}

Machine parts often are subjected to repeated stresses at elevated temperatures and the fatigue deformation of the machine parts caused by repeated stresses may have undesirable effect upon the faculty and the accuracy of these machine parts.

In this paper, the effect of elevated temperatures $\left(100^{\circ} \mathrm{C}, 250^{\circ} \mathrm{C}, 350^{\circ} \mathrm{C}\right)$ upon the fatigue deformations of cold worked and torsional stress-aged $0.37 \% \mathrm{C}$ steels caused by slow cyclic torsional stress was investigated.

The results obtained are as follows:

(1) In cold worked specimen, the more temperature was elevated, the more fatigue yield strength increased, at the range of temperature from room temperature to $250^{\circ} \mathrm{C}$, but at $350^{\circ} \mathrm{C}$ it decreased.

(2) In torsional stress-aged specimen, the more temperature was elevated, the more fatigue yield strength decreased, at the range of temperature up to $250^{\circ} \mathrm{C}$ in $\tau_{a} / \tau_{m} \leqq 1$, but increased in $\tau_{a} / \tau_{m}>1$. And at $350^{\circ} \mathrm{C}$ it decreased in the all values of $\tau_{a} / \tau_{m}$.

(3) It seems that the above behavior of the fatigue yield strength is related to a structural change caused by elevated temperatures and repeated stresses, and especially the remarkable change of the fatigue strength in $\tau_{a} / \tau_{m}>1$ is related to the diminution of the Bauschinger effect caused by these factors.

(4) Torsional stress-aged steel is more useful in preventing the fatigue deformation than cold-worked one at the range of elevated temperature up to $350^{\circ} \mathrm{C}$. (Received Dec. 15, 1958)

\section{1. 緒}

筆者らは $0.37 \% \mathrm{C}$-鋼の焼鈍材, 常温加工材, 㨝り 応力時効処理材について, 常温の繰返し振り試験を行 い, 捩り忘力時効処理が疲労变形の防止に有効である ことを認め, その結果についてはすでに報告した.

しかし機械部品の中には, ある程度の温度ふんい気 中で繰返し応力を受け, しかもこの繰返し応力によっ て生ずる疲労变形がそれらの機能や精度に影響を及ぼ す場合がしばしば見受けられるが，これらに関する研 皆は活とんど見当らない。

ふんい気温度がある程度上昇した場合, 常温加工材 では熱と繰返し応力とによって，更に時効が促進され， 疲学変形の発生が抑制されるであろうと考えられる。

これに反して振り応力時効処理材では一応時効が完了 しているので, その後の加熱による Over aging など

\footnotetext{
* 原稿受付 昭和33年12月15日，当協会の他 2 学会の関西支部て 講演

** 正員 姬路工業大学
}

のため, むしろ渡労变形が助長されるであろうと考え られる.したがって, 常温における応力繰返しの場合 に得られたような結果が，ふんい谷温度の上升した状 態にも, はたして適用しうるかどうか疑問であるので, 前回同様 $0.37 \% \mathrm{C}$-鋼の常温振り加工材, ならびに捩 り応力時効処理材について, 低速㧪り疲労变形に及ぼ す温度の影響について調べた。

\section{2. 試料および実験方法}

奏験に用いた材料, 試験片の形状および寸法は前回 の夷験の場合と同一である．繰返し捩り試験に用いた 試験片は 2 種類で, その一つは焼鈍後常温捩り加工を 施したもの（加工度は塑性せん断ひずみ $\gamma_{p}=0 \cdot 1472$ 苞， 他の一つは捩り応力時効処理（加工度は常温换り加工 したものと同一) したものである. 試験温度は $100^{\circ} \mathrm{C}$, $250^{\circ} \mathrm{C}$ およ゙ $350^{\circ} \mathrm{C}$ の 3 種類で, 応力繰返し速度は 5 回分で手動によった．繰返し㹉り試験の際の加熱およ

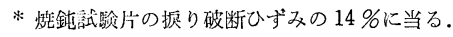


び試験片の固定には応力時効処理の際の装置をそのま ま使用した。まず無負荷状態で加熱して所要の温度に 達した後 10 分経過してから繰返し㹉り試験を始めた。 この場合の加熱温度は電位差計式自動温度調節計によ って $100^{\circ} \mathrm{C}$ では $\pm 11^{\circ} \mathrm{C}, 250^{\circ} \mathrm{C}$ および $350^{\circ} \mathrm{C}$ では \pm 2 Cの範眀に長時間一定に保つことができた。

疲当変形量は, 常温での静摭り試験からあらかじめ 求めておいた試験機つかみ部分間の相対㨝れ角と試験 ケ平行部のせん断ひずみとの関係線図が本実験の温度 範囲でもほとんど適用しうるものと考え，それぞれの 加熱温度のもとでの各繰返し数に対応したつかみ部分 間の塑性的相対㨝れ角在測定し，同線图を利用して試 跧片平行部の塑性残留ひずみを求めた。

なお，㐫力は㹉りモーメントから弾性式によって求 めた公称応力を用いたが，これは本実験の-..つの目橴 である 1000 回の応力繰返し後の塑性变形を $0.2 \%$ 与 える程度の振りモーメントの大いさでは弾性式から求 めたものと, Prandtl の塑性式から求めた応力との相 違が，前加亡と同方向の捩りモーィントの場合にはほ とんどなく, Bauschinger 効果の影響の大きな前加工 と逆方向の振りモーメントの場合でも，その差はわず か $0.5 \mathrm{~kg} / \mathrm{mm}^{2}$ 程度であることがわかったからである。

試験片の固定にキ一を用いているので， キーと固定具の間に少しのガタがあっても 疲労変形の測定䛊差となりやすいので，工 作およびはめ合いに充分注意しておこなっ た。

なお， $\tau_{a} / \tau_{m}$ の值としては $100^{\circ} \mathrm{Cおよび}$ $250^{\circ} \mathrm{C}$ の場合には 0 (応力振幅 $\left.\tau_{a}=0\right) 0 \cdot 4$, $1,3, \infty$ (平均応力 $\tau_{m}=0$ ) の 5 種, $350^{\circ} \mathrm{C}$ の場合には， $0,1, \infty の 3$ 種を選んで行っ た。また，疲労变形量は前処理の際の加工 と同方向に現われるものを(十)，逆方向に 現われるものを(一)として区別して取报っ た。

\section{3. 実験結果およびその考察}

\section{(a) 常温掘り加工材の疲労変形}

常温㹉り加工材が $100 \mathrm{C}, 250 \mathrm{C}, 350 \mathrm{C}$, の温度ふんい気のもとで, 1000 回までの 繰返し㹉り応力受けた場合の疲労変形の 現われ方は, 常温で行った前回の結果とま ったく同様であった。

Fig. 1 は 1 例として, 常温担り加コ材に $250 \mathrm{C}$ の温度ふんい気中で繰返し掎り応力 を加えた場合の繰返し数と疲労变形との関 係を示したものである。同図から明かなよ うに $\tau_{n} / \tau_{m} \leqq 1$ の範囲では, 疲労变形が常 温加工と同方向 $(+)$ に進行するが， $\tau_{a} / \tau_{m}$
$=3$ の場合には, 繰返し応力の大きさによって, 疲労 変形の起る方向が異なる。すなわち, 繰返し振りの最 大応力は前加工と同方向の㧪り比例限より小さいが最 小灿力が前加亡と逆方向の比例限を超える場合には， 加工と逆力向の疲労变形 (一) 在生じ, 繰返しの最大お よび最小㐫力がそれぞれ前加工と同力向，および逆方 向の比例限を超える場合には前加工と同方向の疲労変 形 (十)を生ずるようである。

$\tau_{a} / \tau_{m}=\infty$ の場合には, 疲学变形は最小応力のみの 影響を受け，そのために(一)の疲労変形を生ずる。

Fig. 1 から明かなように疲労变形速度は繰返しの初 期にやや大きいが，繰返し数の増加とともに減少し， ついに疲労変形の進行が停此するような傾向を示す。

この傾向は $100^{\circ} \mathrm{C}, 350^{\circ} \mathrm{C}$ の場合も同様であった。 上述の結果老繰返し最大せん断応力一疲労变形線図に あらわしてみると，Fig. 2 および Fig. 3 のようで,

Fig. 2 は $100^{\circ} \mathrm{C}$ の場合, Fig. 3 は $250^{\circ} \mathrm{C}$ の場合を示 す. Fig. 2 と Fig. 3 を比較して気がつくことは, $100 \mathrm{C}$ の場合には， $\tau_{a} / \tau_{m} \leqq 1$ の範冊で $\tau_{a} / \tau_{m}$ の值に よって，それぞれ別個の線図が得られるにかかわらず， $250^{\circ} \mathrm{C}$ の場合にはほとんど一本の曲線に一致している ことと, 全般に $250^{\circ} \mathrm{C}$ の場合のほうが $100^{\circ} \mathrm{C}$ の場合

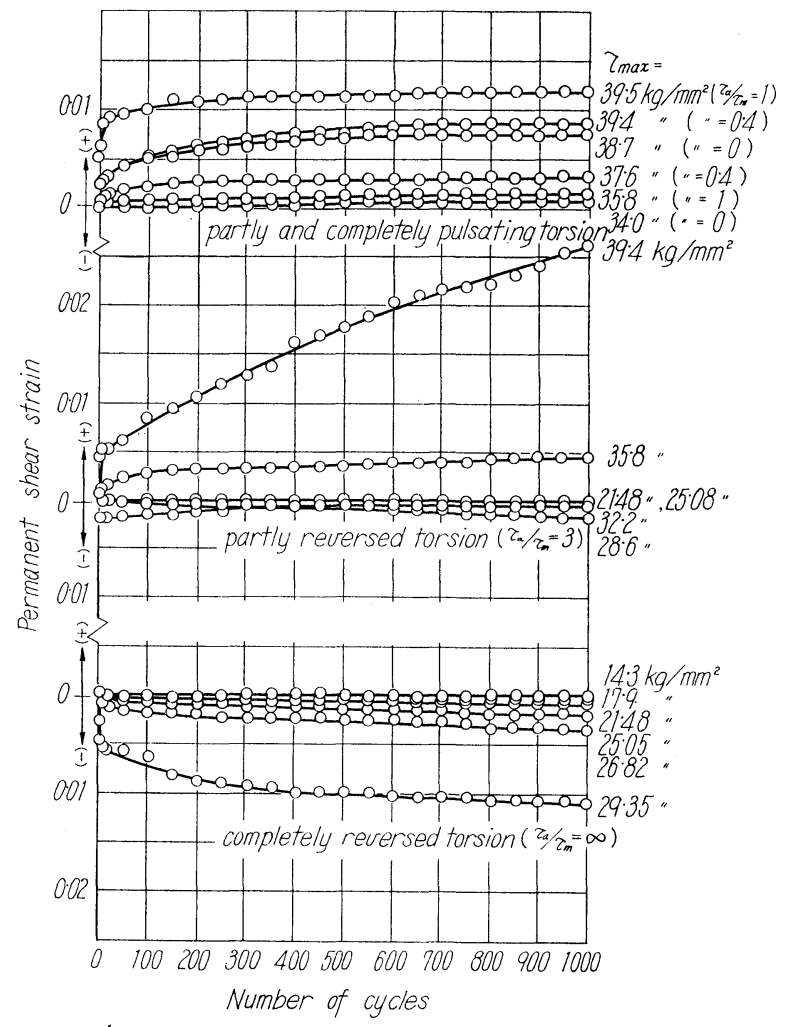

Fig. 1 Relation between permanent shear strain and number of stress cycles for cold worked speucimen $\left(250^{\circ} \mathrm{C}\right)$ 


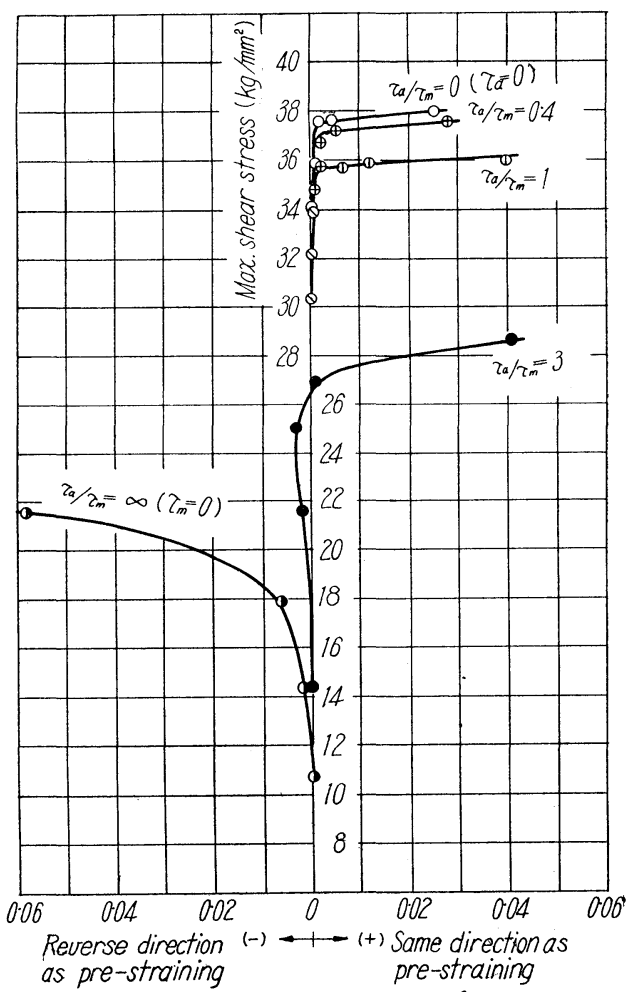

Permanent shear strain after $10^{3}$ stress cycles

Fig. 2 Relation between maximum shear stress and permanent shear strain in fatigue test at $100^{\circ} \mathrm{C}$ (cold worked specimen)

より疲労変形が少くことにこの傾向は $\tau_{a} / \tau_{m}>1$ の 範囲でいちじるしい点である。

$350^{\circ} \mathrm{C}$ の場合の最大せん断応力一疲労变形線図は省 略するが，線図の傾向は $250^{\circ} \mathrm{C}$ の昜合とまったく同様 であった。しかし全般的に $250^{\circ} \mathrm{C}$ の場合より疲労変形 が大きくなった。

\section{(b) 応力時効処理材の疲労変形}

$350^{\circ} \mathrm{C}, 3$ 分の据り応力時効処理を行った材料の疲 労変形の進行する様子は, Fig. 1 の常温加工材の場合 と同様，繰返し数の進むにつれて一定になろうとする 傾向を示した。これは応力時效処理材の常温における 疲学变形が繰返し数とともにますます増加したのと比 較してかなり相違している。

本実験の温度範囲では $\alpha$ 鉄中の $\mathrm{C} や \mathrm{~N}$ などの溶質原 子の拡散速度が大きくなって, 繰返し応力のもとで新 に生じた転位自身の移動速度に近づくために，転位の 移動(疲学变形)が抑制されるためであろうと考えられ る.

以上の結果を繰返し最大せん断応力一疲学変形線図 に表わしてみると Fig. 4 および Fig. 5 のようで， Fig. 4 は $100^{\circ} \mathrm{C}$ の場合, Fig. 5 は $250^{\circ} \mathrm{C}$ の場合を示

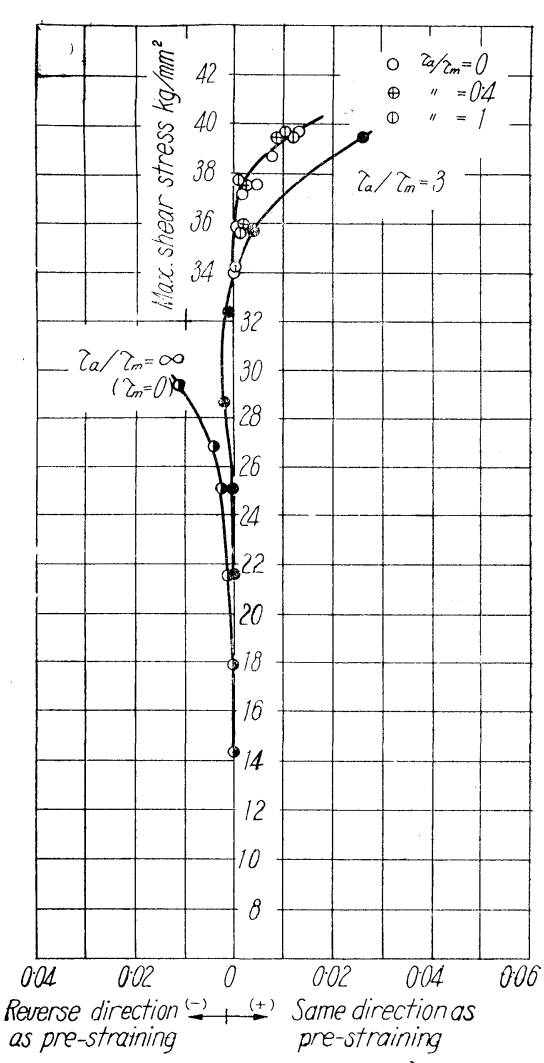

Permanent shear sstrain after $10^{3}$ stress aycles

Fig. 3 Relation between maximum shear stress and permanent shear strain in fatigue test at $250^{\circ} \mathrm{C}$ (cold worked specimen)

す。この場合にも， $\tau_{a} / \tau_{m} \leqq 1$ の範囲では $100^{\circ} \mathrm{C}$ の場 合には $\tau_{a} / \tau_{m}$ の值に応じて別個の曲線で表わされる に対し， $250^{\circ} \mathrm{C}$ の場合には，データーのばらつきを考 慮すると, 一本の曲線で表わされる点は常温加工材の 場合とまったく同様である。 $\tau_{a} / \tau_{m} \leqq 1$ の範四で, 250 ${ }^{\circ} \mathrm{C}$ の場合は $100^{\circ} \mathrm{C}$ の場合より, やや疲労変形が增す 傾向走示すのにもかかわらず， $\tau_{a} / \tau_{m}>1$ の範囲では むしろ $100 \mathrm{C}$ の場合より瘦学变形が減少する傾向を示 していることはきわめて興味深い。

$350^{\circ} \mathrm{C}$ の場合の最大せん断応力一疲労变形線図は省 略するが，この場合には $250^{\circ} \mathrm{C}$ の場合より，全般的に 疲労变形が增加した。

次に，常温掵り加工材および厰り応力時効処理材の 痩学降伏強さ(1000 回の繰返し数における瘦学变形量 $r_{f p}=0.2 \%$ に対応する応力）が平均応力および㐫力 振幅によってどのように变化するかを耐久限度線図で 示してみるとFig. 6 のようになる。ただし，同図中 に前回行った常温での疲学变形試験から得られた結果 も併記して比較に便ならしめた。 


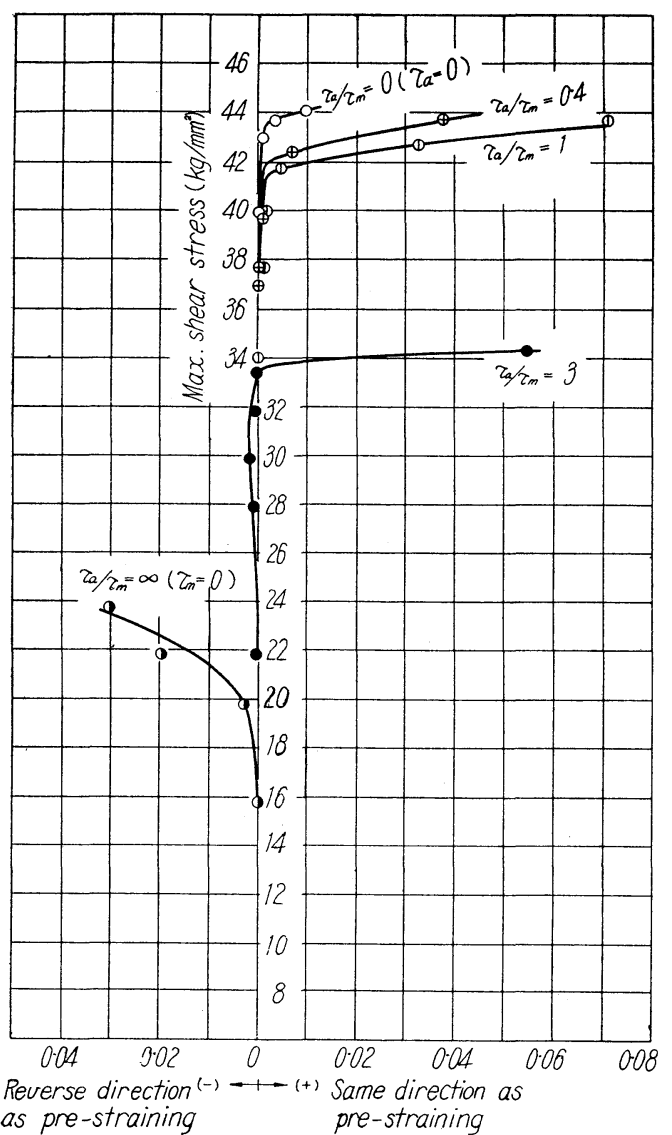

Permanent shear strain after $10^{3}$ stress cycles

Fig. 4 Relation between maximum shear stress and permanent shear strain in fatigue test at $100^{\circ} \mathrm{C}$ (stress aged specimen)

Fig. 6 から明かなように, 常温捩り加工材では, $\tau_{a} / \tau_{m}$ の值のいかんにかかわらず常温から $100^{\circ} \mathrm{C}$ お び $250^{\circ} \mathrm{C}$ までふんい気温度が上年するにつれて疲労降 伏強さが上昇し， $\tau_{a} / \tau_{m}>1$ の範囲で特にこの傾向が

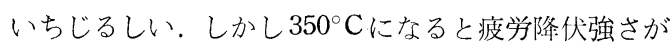
かなり低下することがわかる。

また, 捩り応力時効処理材の疲労降伏強さは, ほぼ $\tau_{a} / \tau_{m} \leqq 1$ の範囲内では, ふんい気の温度が上升する につれて低下するが， $\tau_{a} / \tau_{m}>1$ の範囲では，かえっ て疲労降伏強さが上昇することを示した。しかし, ふ んい気温度がさらに上昇して, $350^{\circ} \mathrm{C}$ に達すると $\tau_{a} /$ $\tau_{m}$ の值のいかんにかかわらず疲労降伏強さが全般的 に低下することは常温㨝り加工材の場合と同様である.

常温㹉り加工材および㨝り応力時効処理材とも, ふ んい気温度が $250^{\circ} \mathrm{C}$ 以上になると， $\tau_{a} / \tau_{m} \leqq 1$ の範囲 で, 疲労降伏強さを表わす曲線はほとんど $45^{\circ}$ の直線 となり, また $250^{\circ} \mathrm{C}$ 場合のみ両振りの疲労降伏強さ が焼䤞材のそれより高い值を示している。

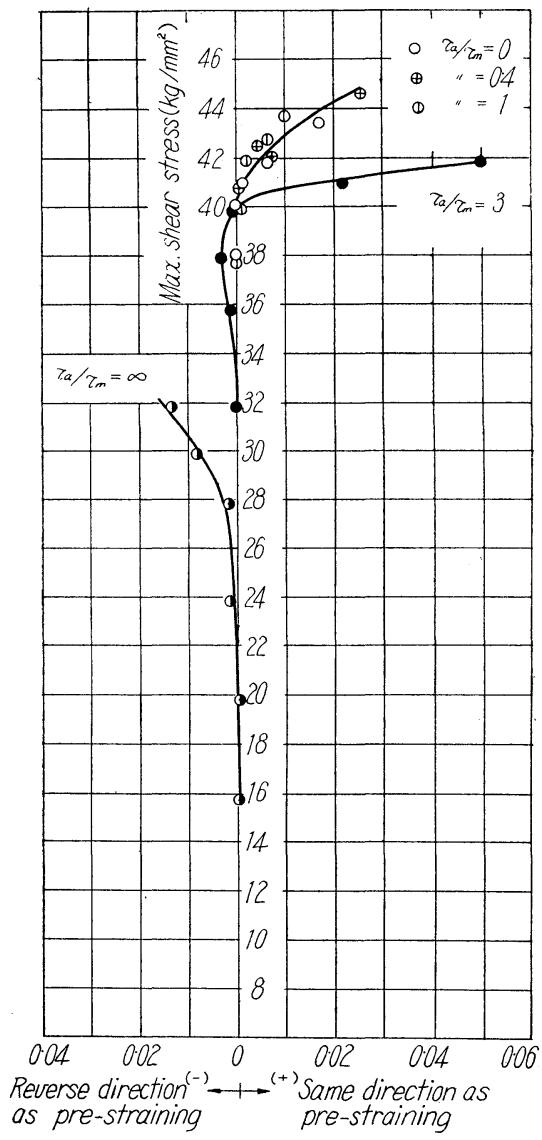

Fig. 5 Relation between maximum shear stress and permanent shear strain in fatigue test at $250^{\circ} \mathrm{C}$ (stress aged specimen)

疲労変形に及ぼす温度の影響を明らかにするために， 緃軸に疲労降伏強さを, 横軸に加熱ふんい気の温度を とって示すと Fig. 7 のようになり, 上述の傾向がさ らに明暸になる。

本実験の場合には, 試験片は予熱に 10 分, 1000 回 の繰返し中に 3 時間 20 分, 合計約 3 時間半の間, 一定 温度に加熱されているので, 以上のような温度ふんい 気による疲労降伏強さの变化は, いずれも温度と繰返 し応力による材質的な变化によるものと考えられる.

すなわち, 常温㧪り加工材では, 温度および繰返し 応力による時効の促進と Bauschinger 効果の変化が, また捩り応力時効処理材では, 温度および繰返し応力 による Over aging と Bauschinger 効果の変化が相 互に関係しているものと考えられる.

繰返し応力またはひずみを加えた場合の金属の組織 や機械的性質の変化に関する研究は, 比較的最近よく 行われているが, Cu. Al. またはその合金の場合が多 く, 鋼に関するこの種の研究は特に少いようである. 


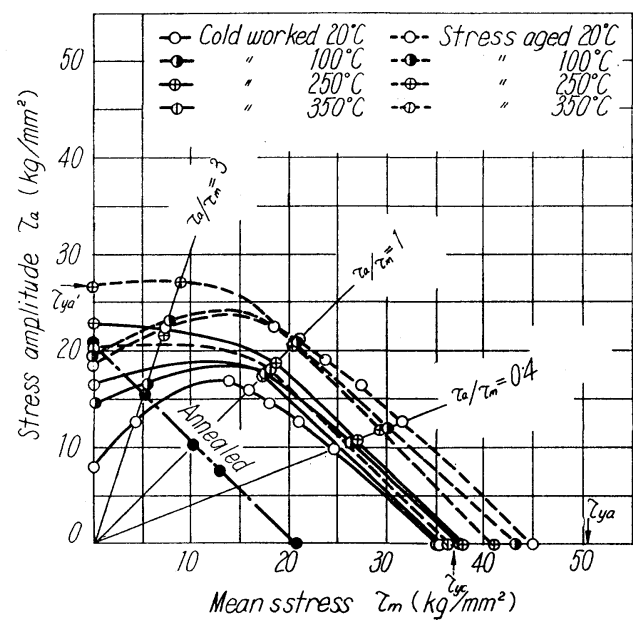

$7 y_{c}$ : yield strength in pre-straining direction of cold worked specimen at room temp.

$\tau_{y a}$ : yield strength in pre-straining direction of stress aged specimen at room temp.

$7 y a^{\prime}$ : yield strength in reverse direction as prestraining of stress aged specimen at room temp.

Fig. 6 Diagram of fatigue deformation

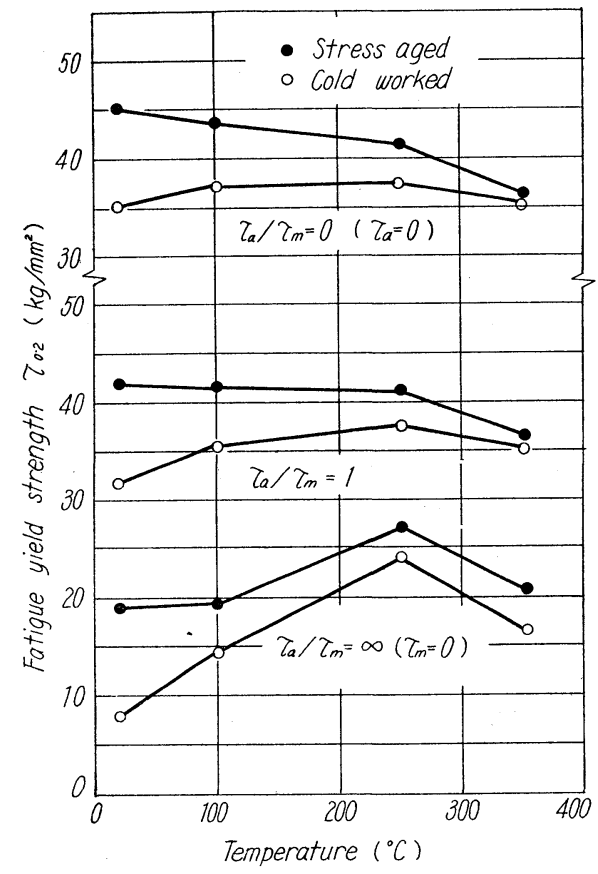

Fig. 7 Effect of elevated temperature on the fatigue yield strength

したがって，温度および繰返し応力によって，上に 推定したような变化が起るかどうかを簡単に断定する ことはできないが，1000回の応力繰返しによって， 常温捩り加工材および捠り応力時効処理材の硬度がど のように变化するかを示すと，それぞれ Table 1 およ
Table 1 Hardness change caused by cyclic stress at elevated temperature (initially cold worked specimen)

\begin{tabular}{c|c|c|c|c}
\hline \multirow{2}{*}{$\tau_{a} / \tau_{m}$} & $\begin{array}{c}\text { Repeated } \\
\text { maximum } \\
\text { shear } \\
\text { stress }\end{array}$ & \multicolumn{3}{|c}{ Increased ratio of hardness $\frac{H_{2}-H_{1}}{H_{0}}$} \\
\hline 0 & $0.95 \tau_{w c}$ & +2.0 & $+\%)$ & $350^{\circ} \mathrm{C}$ \\
1 & $0.95 \tau_{w c}$ & +3.6 & +5.5 & +4.8 \\
$\infty$ & $0.4 \tau_{w c}$ & +4.1 & +4.2 & +3.8
\end{tabular}

$\tau_{w c}:$ Cold working stress of pre-straining

$H_{0}$ : Hardness of annealed specimen

$H_{1}$ : Hardness of cold worked specimen

$H_{2}$ : Hardness after fatigue test at each elevated tempera ure.

Table 2 Hardness change caused by cyclic stress at elevated temperature (initially stress aged specimen)

\begin{tabular}{c|c|c|c|c}
\hline \multirow{2}{*}{$\tau_{a} / \tau_{m}$} & $\begin{array}{c}\text { Repeated } \\
\text { maximum } \\
\text { shear } \\
\text { stress }\end{array}$ & \multicolumn{2}{|c|}{ Increased ratio of hardness $\frac{H_{2^{\prime}}-H_{1^{\prime}}}{H_{0}}$} \\
\hline 0 & $0.95 \tau_{w a}$ & $-1.3 \%$ & -3.4 & -2.1 \\
1 & $0.95 \tau_{w a}$ & -1.7 & -3.4 & -3.8 \\
$\infty$ & $0.4 \tau_{w a}$ & -0.2 & -0.9 & -1.1 \\
\hline
\end{tabular}

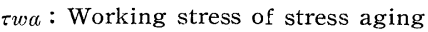

$H_{0}$ : Hardness of annealed specimen

$H_{1}^{\prime}$ : Hardness of stress aged specimon

$H_{2}^{\prime}$ : Hardness after fatigue test at each elevated temperature.

び Table 2 のようである.

いずれも $r_{f p}=0.2 \%$ 程度以下のものについて，応 力繰返し前後の Rockwell 硬度を測定した結果から 得られたものである。これらのTableから明かなよう に, 疲労变形量を活ぼ揃えて比較しようとしたために， $\tau_{a} / \tau_{m}=\infty$ の場合のみ繰返し応力が低く, かつ常温㨝 り加工材と捩り応力時効処理材とでは繰返し応力の值 は異なっている。また，両処理材の硬度にも差がある ので一律に比較することは困難である。しかし, 常温 据り加工材の 1000 回の応力繰返し後の硬度は, 繰返 しの際のふんい気温度が $100^{\circ} \mathrm{C}$ から $250^{\circ} \mathrm{C}$ 一上舁する

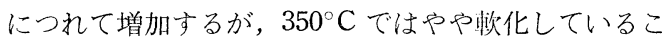
とがわかる．また，振り応力時効処理材では温度の上 萛とともに軟化するが, 両振応力の繰返しの場合の㰞 化程度はやや少いことがわかる。

以上の結果から, 温度と繰返し応力とによって繰返 し試験中に，なんらかの材質的な变化が起っているこ とが推定される。すなわち, 常温加工材では温度 $(250$ ${ }^{\circ} \mathrm{C}$ まで) と繰返し応力とによって, 時効が促進されて 硬化し，比例限志よび降伏強さが上昇する。また，㹉 り応力時効処理材では Over aging または回復によっ 
Table 3 Change of proportional limit and yield strength in reverse direction as pre-straining caused by various treatments

\begin{tabular}{|c|c|c|}
\hline \multicolumn{3}{|c|}{ Cold worked } \\
\hline Treatment & $\begin{array}{c}\text { Proportional } \\
\text { limit } \\
\tau c_{c^{\prime}}\left(\mathrm{kg} / \mathrm{mm}^{2}\right)\end{array}$ & $\begin{array}{l}\text { Yield strength } \\
\tau_{y c^{\prime}}\left(\mathrm{kg} / \mathrm{mm}^{2}\right)\end{array}$ \\
\hline as cold worked & 0 & $7 \cdot 5$ \\
\hline $\begin{array}{l}1000 \text { stress cycles } \\
\text { at room temp. }\end{array}$ & $15 \cdot 5$ & $21 \cdot 8$ \\
\hline $\begin{array}{c}1000 \text { stress cycles } \\
\text { at } 100^{\circ} \mathrm{C}\end{array}$ & $18 \cdot 5$ & $22 \cdot 5$ \\
\hline $\begin{array}{c}1000 \text { stress cycles } \\
\text { at } 250^{\circ} \mathrm{C}\end{array}$ & $22 \cdot 7$ & $26 \cdot 5$ \\
\hline $\begin{array}{c}1000 \text { stress cycles } \\
\text { at } 350^{\circ} \mathrm{C}\end{array}$ & $21 \cdot 5$ & $25 \cdot 1$ \\
\hline \multicolumn{3}{|c|}{ Stress aged } \\
\hline Treatment & $\begin{array}{c}\text { Proportional } \\
\text { limit } \\
\tau p_{\alpha^{\prime}\left(\mathrm{kg} / \mathrm{mm}^{2}\right)}\end{array}$ & $\begin{array}{l}\text { Yield strength } \\
\tau_{u^{\prime}}\left(\mathrm{kg} / \mathrm{mm}^{2}\right)\end{array}$ \\
\hline as stress aged & 17 & $26 \cdot 5$ \\
\hline $\begin{array}{l}1000 \text { stress cycles } \\
\text { at room temp. }\end{array}$ & $20 \cdot 7$ & $27 \cdot 0$ \\
\hline $\begin{array}{c}1000 \text { stress cycles } \\
\text { at } 100^{\circ} \mathrm{C}\end{array}$ & $23 \cdot 0$ & $27 \cdot 0$ \\
\hline $\begin{array}{c}1000 \text { stress cycles } \\
\text { at } 250^{\circ} \mathrm{C}\end{array}$ & $24 \cdot 0$ & $27 \cdot 5$ \\
\hline $\begin{array}{l}1000 \text { stress cycles } \\
\text { at } 350^{\circ} \mathrm{C}\end{array}$ & $21 \cdot 8$ & $25 \cdot 5$ \\
\hline \multicolumn{3}{|c|}{$\begin{array}{c}\tau_{p c^{\prime}}, \tau_{p c^{\prime}}: \text { proportinal limit in reverse direction as } \\
\text { pre-straining } \\
\tau_{y / c^{\prime}} \tau_{y \alpha^{\prime}}: \text { yield strength in reverse direction as }\end{array}$} \\
\hline
\end{tabular}

て㷡化し，此例限および降伏強さが低下してくる。 のため Fig. 6 の $\tau_{a} / \tau_{m} \leqq 1$ の範囲の線図で示される ような疲労降伏強さの上其(常温加工材), あるいは低 下(応力時効材)を起すものと了解することができる。

しかし，硬度は機械的性質の異方性を表わすことが できないから, Fig. 6 の $\tau_{n} / \tau_{m}>1$ の籁囲の線図で示 されるような, 瘦労降伏強さの上昇を生ずるためには， 常温捩り加工材および据り応力時効処理材共, $250 \circ \mathrm{C}$ までのふんい気温度と繰返し応力とによって, 前加工 と逆方向の比例限や, 降伏強さが増加しなければなら ない。

各温度ふんい気で比例限や，降伏強さを測定するこ とは困難であるので, 各温度で 1000 回の両振り捩り 繰返し応力を加えた，常温㨝り加工材および据り応力 時効処理材 (1000 回繰返し後の疲学变形量 $\gamma_{f p}=0.2$ \%以下のもの）について, 前加工と逆方向の常温静㧪 り試験を行い, 㧪れ角を鏡と望遠鏡を使用して求め, 比例限および降伏強さを求めた結果を示すと Table 3
のようである。

これから常温㹉り加工材および㹉り応力時効処理材 ともに, 温度および繰返し応力によって前加工と逆方 向の比例限および降伏強さが上昇し, $350^{\circ} \mathrm{C}$ になって 初めて低下与ることがわかる。したがって, 疲労降伏 強さが温度によって, Fig. 6 や Fig. 7 に示すように 变化することは, 温度と繰返し応力とによって, 繰返 し試験中に起る材質的な变化と密接な関係があること が明かとなった。

\section{4. 結果 の 総 括}

常温の場合に引続いて $100^{\circ} \mathrm{C}, 250^{\circ} \mathrm{C}$ および $350^{\circ} \mathrm{C}$ の温度ふんい気において $0.37 \% \mathrm{C}$-鋼の低速㹉り疲学 変形がどのように变るかを調べた。

その結果は次のように総括することができる。

（1）常温捱り加工材では常温から $250^{\circ} \mathrm{C}$ までは温 度が上帠するにつれて, 疲労降伏強さが増加し, 350 ${ }^{\circ} \mathrm{C}$ に達すると低下寸る。

(2) 㨝り応力時効処理材では, $\tau_{a} / \tau_{m} \leqq 1$ の簌囲 では温度の上年するにつれて, 疲労降伏強さが低下す るが， $\tau_{a} / \tau_{m}>1$ の範用では, $250^{\circ} \mathrm{C}$ まで温度が上昇 するにつれて, 疲労降伏強さが増加し, $350 \mathrm{C}$ に達す ると低下する。

（3）以上のような痩労降伏強さの变化は, 温度と 忍力とによって, 繰返し試験中に起る材質的な変化と 関係があり，ことに $\tau_{a} / \tau_{m}>1$ の範团での変化は温度 と繰返し応力による Bauschinger 効果の減少と密接 な関係があると考えられる。

（4）本実験で行った程度の温度ふんい気のもとで は, 常温加工材に比較して, 㹉り応力時効処理材の方 が疲労変形の防非に有効である。

終りに臨み種々御指導, 御批判を賜わった大阪大学 工学部深田軍治教授に深甚なる謝意を表し，実験に熱 心に協力された，表宗三，岡田広次，武内鏡の三君に 感謝する。

\section{参 考 交 献}

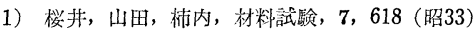

2) F.P. Bullen, A.K. Head. and W.A. Wood, Proc. Roy. Soc. A. 216, 332 (1953)

3) Polakowski and A. Palchoudhuri, Proc. A.S.T.M., 54, 701 (1954)

4) T. Broom, J.H. Molineux and V.N. Whittaker, J. Inst. Metals, 84, 357 (1955)

5) T. Broom and R.K. Ham, Proc. Roy. Soc. A., 242, 166 (1957)

6) W.A. Wood and R.L. Segall, Proc. Roy. Soc. A., 242 180 (1957) 